\title{
FROM THE DIARY
}

\author{
Sylvia Townsend Warner
}

I gor out the old willow-pattern curtains, and cut and machined them into curtains for the long book-shelves, full of our disgracefully childish and naughtily Left-ish books. As I machined I felt as though I was desecrating a great deal of my past. I bought the stuff when we came to this house, remembering the Sturt's staircase, and proud to be buying Morris. They hung in her room through the first Elizabethiad and all through the war, yellowing with tobacco smoke and fading with sun, and never being properly cleaned by war-time cleaners. And they were always a pleasure to me, my eyes would follow their calm design while the wireless brayed out its calamities, and its boring mendacious war-features. And they saw my darling Thomas growing majestic - and growing old, for in the summer of ' 49 I put them back again. Unpicking their seams this evening I saw again the original pure white and solemn green, as though I had unpicked a piece of myself.' 